\section{Allergy to Spathiphyllum wallisii, an Indoor Allergen}

Herrera-Lasso Regás V ${ }^{1}$, Dalmau Duch G ${ }^{1}$, Gázquez García V1, Pineda De La Losa $\mathrm{F}^{2}$, Castillo Fernández $\mathrm{M}^{2}$, Garnica Velandia $\mathrm{D}^{1}$, Gaig Jané $\mathrm{P}^{1}$

${ }^{1}$ Allergy Department, University Hospital Joan XXIII, Tarragona, Spain; Pere Virgili Health Research Institute (IISPV)

${ }^{2}$ Diater Laboratory, Madrid, Spain

J Investig Allergol Clin Immunol 2019; Vol. 29(6): 453-454 doi: 10.18176/jiaci.0419

Key words: Spathiphyllum wallisii. Respiratory allergy. Indoor allergen. Rhinitis. Asthma.

Palabras clave: Spathiphyllum wallisii. Alergia respiratoria. Alérgeno de interior. Rinitis. Asma.

Spathiphyllum wallisii is an indoor ornamental house plant belonging to the Araceae family, which comprises 36 known species of Spathiphyllum found in tropical areas [1-3]. These plants may contain alkaloids, calcium oxalate crystals, and proteolytic enzymes [3]. Cases of contact dermatitis and occupational allergy (eg, rhinoconjunctivitis, asthma, and urticaria) have been reported in persons exposed to $S$ wallisii [1,3-5]. Allergy to houseplants is rare [2-5]. We report a case of hypersensitivity to $S$ wallisii.

The patient was a 34-year-old white woman with allergy to lipid transfer proteins and shellfish and rhinoconjunctivitis due to house dust mites, grass pollen, and Platanus pollen. She also experienced hypersensitivity to cat dander. Her condition was well controlled with specific immunotherapy for house dust mites. At a routine visit, she reported immediate episodes of bronchospasm associated with severe rhinoconjunctivitis on returning home. She related her symptoms to the spathe flower she was recently given.

Prick testing was performed with standard aeroallergens, including latex and palm profilin (Leti). Prick-by-prick tests were performed on the patient and on both atopic and nonatopic controls with flower spikes the patient had brought from home. Basic pulmonary function testing (spirometry) and specific blood testing with ImmunoCAP determinations of grass profilin (Phl p 12) and Pru p 3 were conducted, as were in vitro SDSPAGE and immunoassays of the flower's spikes, leaves, and stem. Prick testing was performed as follows. A flower spike was slightly crushed and placed on the patient's skin in a drop of physiological saline solution. A positive test result was defined as a wheal of at least $3 \mathrm{~mm}$. The allergenic extract of the flower spikes, leaves, and stem was made with the sample donated by the patient. The samples were chopped and suspended in phosphate-buffered saline. After homogenization for 2 hours at $4^{\circ} \mathrm{C}$, the supernatants were centrifuged and separated. Next, they were dialyzed and lyophilized. Protein concentrations were measured according to the Bradford technique [6]. The proteins of the extracts were separated by SDS-PAGE and then transferred to a membrane for further incubation with the patient's serum.

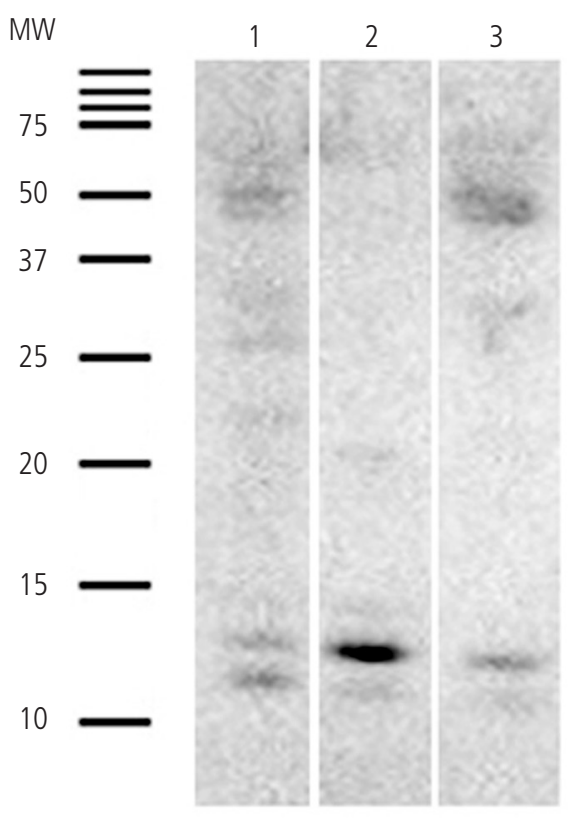

Figure. Immunoblot. Lane 1, extract of flower spikes; Lane 2, extract of leaves; Lane 3, extract of stem. Several protein bands ranging between 11 and $14 \mathrm{kDa}$ can be seen, with a 13-kDa band in the allergenic extract of leaves, which is of greater intensity. MW indicates molecular weight (in $\mathrm{kDa}$ ).

The prick-by-prick test with the flower was positive, with a wheal diameter of $3 \mathrm{~mm}$ after the first 15 minutes. This doubled in size, with an erythema diameter of $20 \mathrm{~mm}$ after 45 minutes, in both atopic and nonatopic negative controls. The natural rubber latex prick test was negative. Negative results were also recorded in the prick test for palm profilin and the ImmunoCAP determination result for grass profilin ( $\mathrm{Phl} \mathrm{p} \mathrm{12).} \mathrm{The} \mathrm{result} \mathrm{of}$ spirometry was normal $\left(\mathrm{FEV}_{1}>80 \%\right)$, and the patient's serum was positive for Pru p 3 (ImmunoCAP).

The in vitro immunoblot test revealed several protein bands ranging between $11 \mathrm{kDa}$ and $14 \mathrm{kDa}$, with a more intense $13-\mathrm{kDa}$ band in the allergenic leaf extract.

Occupational allergy caused by plants has been reported in patients who are continually exposed, such as florists and gardeners $[2,4,7]$. Hypersensitivity to indoor ornamental houseplants, on the other hand, is rarely reported. Yucca (Yucca aloifolia), ficus (Ficus benjamina), and the Spathiphyllum genus are the most studied indoor plants with respect to this condition, and a high degree of cross-reactivity between them has been reported $[1,3]$. Allergy to spathe flower $[1,2,4,5]$ is characterized by a heavy band of about $14 \mathrm{kDa}$ in IgE immunoblotting. This has not been fully identified, although it has the same molecular mass as profilins [4]. Furthermore, proteins with a molecular weight of 14-15 $\mathrm{kDa}$ have been recognized in various vegetables and in rubber latex $[1,7-9]$, thus justifying possible cross-reactivity between these plants.

The patient we report was tested only for $S$ wallisii owing to the clear cause-effect relationship based on the patient's symptoms on exposure, the absence of exposure to other indoor house plants, and her clear improvement after withdrawal of the plant. Prick testing with palm profilin and latex was negative, as was ImmunoCAP with grass profilin. For that 
reason, the protein bands detected in IgE immunoblotting (11$14 \mathrm{kDa}$ ) could be indicative of sensitization to $S$ wallisii, since we cannot ensure that profilin or a profilin with a low crossreactivity pattern is the protein responsible for hypersensitivity in this case, as suggested elsewhere.

It is important to consider ornamental houseplants that do not produce pollen as possible sources of indoor allergens, since other parts of these plants may cause immediate hypersensitivity and may be more likely to do so than common molds, house dust mites, and pet hair or dander.

\section{Funding}

The authors declare that no funding was received for the present study.

\section{Conflicts of Interest}

The authors declare that they have no conflicts of interest.

\section{References}

1. Kanerva L, Estlander T, Aalto-Korte K. Occupational protein contact dermatitis and rhinoconjunctivitis caused by spathe (Spathiphyllum) flowers. Contact Dermatitis. 2000 Jun;42(6):369-70.

2. Cahen $Y D$, Lundberg $M$, Wüthrich $B$. Indoor allergy to spathe flower (Spathiphyllum floribundum). Allergy. 1997 Jan;52(1):114-5.

3. Mitchell J, et al. Plants and plant products injurious to the skin. Vancouver, British Columbia, Canada: Greengrass Ltd, 1979

4. Kanerva L, Mäkinen-Kiljunen S, Kiistala R, Granlund H. Occupational allergy caused by spathe flower (Spathiphyllum wallisii). Allergy. 1995 Feb;50(2):174-8.

5. Kanerva L, Estlander T, Petman L, Mäkinen-Kiljunen S. Occupational allergic contact urticaria to yucca (Yucca aloifolia), weeping fig (Ficus benjamina), and spathe flower (Spathiphyllum wallisii). Allergy. 2001 Oct;56(10):1008-11.

6. Bradford MM. A rapid and sensitive method for the quantitation of microgram quantities of protein utilizing the principle of protein-dye binding. Anal Biochem. 1976 May 7;72:248-54.

7. Purillä $P$, Keskinen $H$, Leino $T$, Tupasela $O$, Tuppurainen $M$. Occupational asthma caused by decorative flowers: review and case reports. Int Arch Occup Environ Health. 1994;66(2):131-6.

8. Jordan-Wagner DL, Whisman BA, Goetz DW. Crossallergenicity among celery, cucumber, carrot, and watermelon. Ann Allergy. 1993 Jul;71(1):70-9.

9. Mäkinen-Kiljunen $S$, Turjanmaa $K$, Palosuo $T$, Reunala T. Characterization of latex antigens and allergens in surgical gloves and natural rubber by immunoelectrophoretic methods. J Allergy Clin Immunol. 1992 Aug;90(2):230-5.

Manuscript received November 13, 2018; accepted for publication May 20, 2019.

\footnotetext{
Valeria Herrera-Lasso Regás

Allergy Department

University Hospital Joan XXIII

Tarragona, Spain

E-mail: vherreralasso@gmail.com
} 